\title{
Colony-specific foraging areas of lactating New Zealand fur seals
}

\author{
Alastair Martin Mitri Baylis ${ }^{1,2,3, *}$, Brad Page $^{2}$, Simon David Goldsworthy $^{2}$ \\ ${ }^{1}$ School of Earth and Environmental Sciences, University of Adelaide, Adelaide, South Australia 5005, Australia \\ ${ }^{2}$ South Australian Research and Development Institute (Aquatic Sciences), PO Box 120, Henley Beach, \\ South Australia 5022, Australia
}

${ }^{3}$ Present address: Fisheries Department, Falkland Islands Government, PO Box 598, Stanley, Falkland Islands

\begin{abstract}
During 2005 and 2006, 21 lactating New Zealand fur seals Arctocephalus forsteri were tracked from 4 breeding colonies in southern Australia. The distance between colonies ranged between 46 and $207 \mathrm{~km}$. In total, 101 foraging trips were recorded (2 to 19 trips ind. ${ }^{-1}$ ). Seals initiated foraging trips on a colony-specific bearing (Cape Gantheaume $141 \pm 34^{\circ}$, Cape du Couedic $188 \pm 12^{\circ}$, North Neptune Island $204 \pm 12^{\circ}$ and Liguanea Island $235 \pm 19^{\circ}$ ). During autumn, seals from Cape du Couedic, North Neptune Island and Liguanea Island predominantly targeted distant oceanic waters associated with the subtropical front (STF), while seals from Cape Gantheaume targeted shelf waters associated with a seasonal coastal upwelling, the Bonney upwelling. The distance of each colony from the STF (based on the preferred colony bearing) or the Bonney upwelling in the case of Cape Gantheaume was correlated with the maximum straight-line distances travelled (Cape Gantheaume $119 \pm 57 \mathrm{~km}$, Cape du Couedic $433 \pm 99 \mathrm{~km}$, North Neptune Island $564 \pm 97 \mathrm{~km}$ and Liguanea Island $792 \pm 82 \mathrm{~km}$ ). The organisation of colony-specific foraging grounds appears to be influenced by the proximity of colonies to predictable local upwelling features, as well as distant oceanic frontal zones. Knowledge of whether New Zealand fur seals utilise colony-specific foraging grounds may be important in predicting and identifying critical habitats and understanding whether management requirements are likely to vary between different colonies.
\end{abstract}

KEY WORDS: Colony separation - Subtropical front · Foraging ecology $\cdot$ New Zealand fur seal · Meta-population

Resale or republication not permitted without written consent of the publisher

\section{INTRODUCTION}

Central place foraging theory predicts that animals either forage within close proximity to the central place provided that sufficient energy can be obtained, or they forage further from the central place if they can more than offset the increased travel costs through greater rates of energy uptake (Orians \& Pearson 1979). As a result, the spatial distribution of foraging effort by a central place forager is likely to be influenced by a combination of previous experience and foraging success, local environmental cues and the needs of nutritionally dependant offspring (Bonadonna et al. 2001, Staniland \& Boyd 2003). The way in which central place foragers distribute their effort to optimise foraging success may also be regulated by the spatial partitioning of foraging areas (Sutherland 1983, Matthiopoulos et al. 2005). For instance, in a meta-population scenario, where groups of spatially separated populations have the ability to overlap foraging areas, competition from conspecifics may influence the distribution of foraging effort and give rise to colony-specific foraging areas.

Among marine central place foragers, colonyspecific foraging areas have been documented for Antarctic fur seals Arctocephalus gazella (Boyd et al. 2002, Lea et al. 2002), northern fur seals Callorhinus ursinus (Robson et al. 2004), blue-eyed shags Phalacro- 
corax articeps (Wanless \& Harris 1993), shy albatross Diomedea cauta (Brothers et al. 1998), Adelie penguins Pygoscelis adeliae (Ainley et al. 2004) and cape gannets Morus capensis (Gremillet et al. 2004). These studies suggest that the development of colonyspecific foraging areas may be important in the partitioning of marine resources where multiple colonies occur in close proximity. In such cases, colony-specific foraging areas may reduce localised resource depletion, either during the early stages of the breeding cycle, when offspring are young, which may necessitate short foraging trips within close proximity to the colony, or in later stages of the breeding cycle, when individuals may travel further to forage (e.g. Harcourt et al. 2002, Thompson et al. 2003, Page et al. 2006).

Colony-specific foraging areas require that individuals travel in colony-specific directions when commencing a foraging trip, indicating highly integrated individual behaviour at the colony level (Bernstein et al. 1991, Robson et al. 2004). Site fidelity to foraging areas is an important factor in reinforcing colony-specific foraging areas and is likely to be influenced by the availability of resources encountered during the previous foraging trip (Bonadonna et al. 2001, Robson et al. 2004, Matthiopoulos et al. 2005). Consequently, it is expected that the function of colony-specific foraging areas is dependent on some degree of habitat predictability in terms of the location, accessibility and quality of resources and the associated predictability in reproductive outcome (Switzer 1993, Irons 1998).

The New Zealand fur seal Arctocephalus forsteri is the most abundant fur seal species in the Australian-New Zealand region (Goldsworthy et al. 2003). In the state of South Australia, New Zealand fur seals breed at 36 locations, which represent $\sim 85 \%$ of the Australian population (Shaughnessy 2005). However, of the 36 breeding colonies, 5 colonies within a $200 \mathrm{~km}$ radius account for $\sim 82 \%$ of the Australian population and produce 17600 pups each year (Shaughnessy 2005). These primary colonies are Cape Ganthueame and Cape du Couedic on Kangaroo Island, North and South Neptune Islands and Liguanea Island, and they form a region of critical habitat for this species (Fig. 1). Accordingly, New Zealand fur seals within South Australia provide a tractable species to assess whether

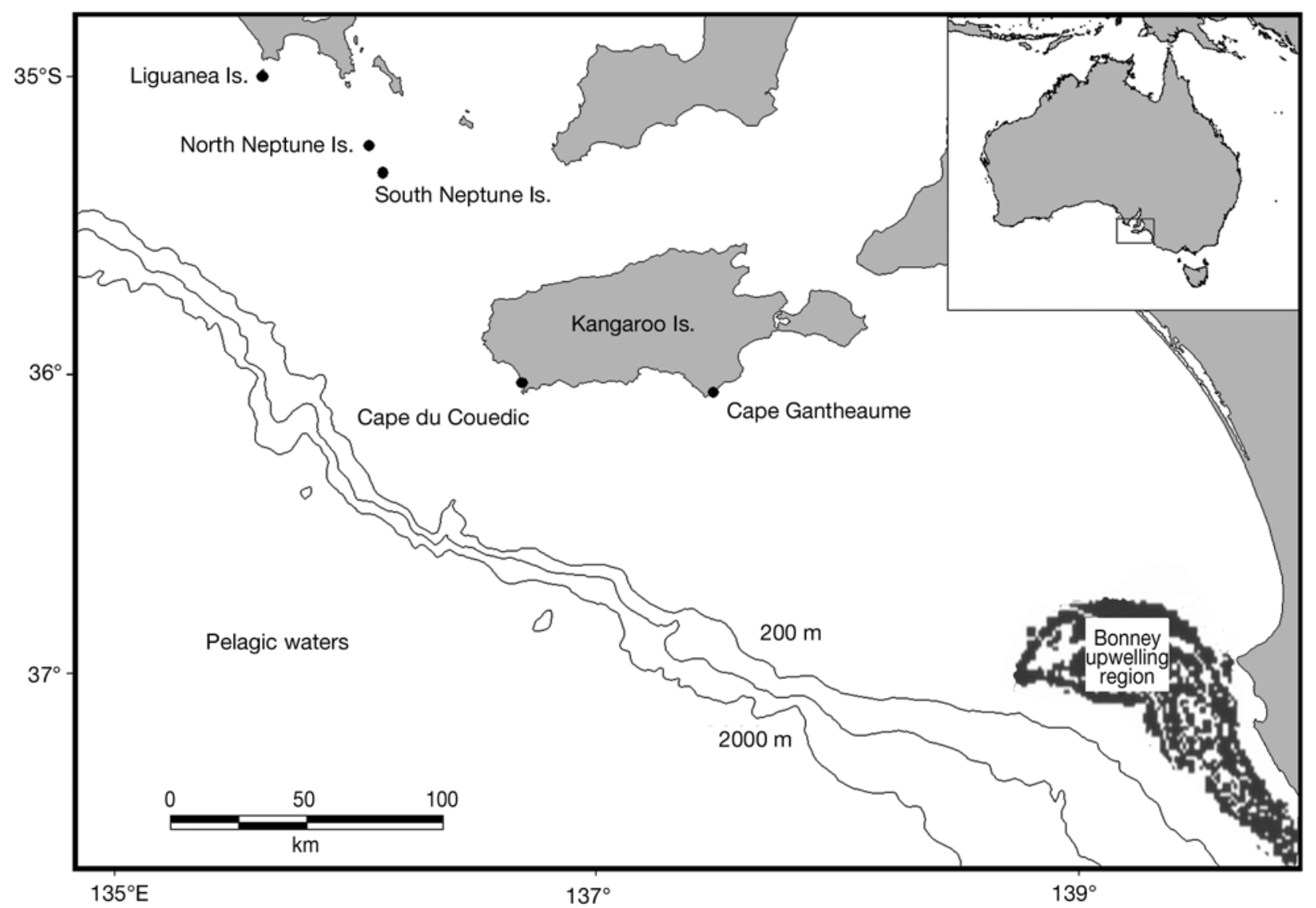

Fig. 1. The study area, showing the 4 study sites: Cape Gantheaume, Cape du Couedic, North Neptune Island and Liguanea Island. Also shown are South Neptune Island, and an example of a cold-water plume that is indicative of the Bonney upwelling during austral summer months 
colonies in close proximity utilise colony-specific foraging areas.

As a result of their abundance and size, New Zealand fur seals are believed to consume the greatest biomass of pelagic resources within the Great Australian Bight of all marine mammal and seabird species (Goldsworthy et al. 2003). Nevertheless, despite the importance of New Zealand fur seals as top predators, their increasing abundance and the potential for fisheries interactions, our understanding of their foraging behaviour and the distribution of their foraging efforts is currently restricted to one colony, Cape Gantheaume on Kangaroo Island (see Page et al. 2006). The Cape Gantheaume colony is unique because it is within close proximity to the largest seasonal coastal upwelling in southern Australia, the Bonney upwelling (Lewis 1981, Butler et al. 2002). The Bonney upwelling is driven by alongshore winds. Between November and late April upwelled cold-water plumes are regularly observed at the sea surface and are associated with elevated nutrient concentrations that support enhanced levels of primary productivity (Butler et al. 2002). Lactating fur seals from Cape Gantheaume are known to target the Bonney upwelling (Page et al. 2006) and the subtropical front (STF) (Baylis et al. unpubl. data). The STF is a major ocean boundary that separates warm, saline, nutrient-poor subtropical waters to the north of the STF from relatively cool, lesssaline, nutrient-rich subantarctic waters to the south (Bradford-Grieve et al. 1999). This front is a continuous oceanographic feature south of Australia, but is reported to end at the continental shelf of western Bass Straight near $40^{\circ} \mathrm{S}$ (Tomczak et al. 2004).

Given the close proximity of the largest New Zealand fur seal colonies to each other within southern Australia, knowledge of how colony-specific foraging grounds influence the spatial distribution of foraging effort may be important in predicting and identifying critical habitats. Furthermore, understanding the distribution of foraging effort across major breeding colonies is important in assessing the potential for fisheries interactions. This study aims to provide this knowledge by (1) comparing the habitat utilisation of New Zealand fur seals across 4 breeding colonies in south eastern South Australia, and (2) investigating whether the proximity of key oceanographic features influences colony-specific foraging grounds.

\section{MATERIALS AND METHODS}

Study site. This study was conducted at 4 sites: Cape Gantheaume $\left(36^{\circ} 04^{\prime} \mathrm{S}, 137^{\circ} 27^{\prime} \mathrm{E}\right)$ and Cape du Couedic $\left(36^{\circ} 03^{\prime} \mathrm{S}, 136^{\circ} 42^{\prime} \mathrm{E}\right)$ on Kangaroo Island, North Neptune Island ( $\left.35^{\circ} 13^{\prime} \mathrm{S}, 136^{\circ} 03^{\prime} \mathrm{E}\right)$ and $\mathrm{Li}-$ guanea Island $\left(34^{\circ} 59^{\prime} \mathrm{S}, 135^{\circ} 37^{\prime} \mathrm{E}\right)$ (Fig. 1). Pup production in southern Australia indicates that New Zealand fur seal Arctocephalus forsteri populations are still recovering following the cessation of 19th and 20th century harvesting (Shaughnessy 2005). The estimated number of pups born during the 2005/2006 breeding season was 3120 at Cape Gantheaume, 2488 at Cape du Couedic, 4391 at North Neptune Island and 2072 at Liguanea Island (P. Shaughnessy \& S. Goldsworthy unpubl. data). While Cape Gantheaume is within close proximity to the Bonney upwelling region, Cape $\mathrm{du}$ Couedic is the closest colony to the continental slope and the STF, the latter of which lies between 39 and $40^{\circ} \mathrm{S}$ (James et al. 2002, Kostianoy et al. 2004). North Neptune Island and Liguanea Island are the furthest colonies from the continental slope and the STF (Fig. 1).

Animal capture and handling. The foraging locations and directional movement of females were monitored using Kiwisat 101 satellite transmitters (Sirtrack) during 2005 and 2006. All units were deployed in April (post-moult), with multiple foraging trips recorded from the same individual to assess foraging site fidelity.

Lactating adult females were captured using a hoop net and manually restrained. Upon capture, anaesthesia was induced and maintained using Isoflurane (Veterinary Companies of Australia), administered via a portable gas anaesthetic machine (Komesaroff Small Animal Anaesthetic Machine, Medical Developments Australia). Standard total length (nose to tail) and axillary girth were measured to the nearest centimetre. Satellite transmitters were attached to guard hairs on the mid-dorsal line using a flexible araldite epoxy (Araldite 2017, Vantico). Devices were removed by cutting guard hairs attached to the unit using a scalpel blade. For certain re-captures, females were first immobilised with Zoletil (dose $2 \mathrm{mg} \mathrm{kg}^{-1}$; Virbac), administered using $0.5 \mathrm{cc}$ barb-less darts (Darts: PneuDart), fired from a $\mathrm{CO}_{2}$-powered tranquilliser gun (Taipan 2000, Tranquil Arms Company). The lightly anaesthetised females were then captured using a hoop net and manually restrained.

Satellite transmitter data treatment. The duration of a foraging trip was defined as the period of time between a seal's departure from the breeding site and its return to land (Page et al. 2006). Satellite location data were obtained through CLS ARGOS (Toulouse, France). The Location-Class B and Z positions were omitted due to the magnitude of their error (Robson et al. 2004). To further improve the accuracy of satellite tracks, the R statistical software (Version 2.0.1, R Development Core Team, R Foundation for Statistical Computing) and timeTrack package (Version 1.0-9, M. D. Sumner, University of Tasmania) were used to 
apply the filter described by McConnell et al. (1992), based on a maximum horizontal speed of $2 \mathrm{~m} \mathrm{~s}^{-1}$ (Page et al. 2006). We assumed a constant horizontal speed between the filtered locations and interpolated a new position for each hour of time along the satellite track (Page et al. 2006).

Several parameters were calculated to summarise the spatial distribution of foraging effort. These parameters were extracted at 60 min time intervals along each interpolated satellite track (except for parameters that described minima, maxima, or totals). Behavioural parameters were calculated to describe (1) cumulative total distance travelled (sum of distances between locations), (2) maximum straight-line distance from the colony to the distal point reached, (3) linearity index (LI) values for outbound and inbound portions of each foraging trip (maximum straight-line distance/total distance) (Robson et al. 2004), (4) bearing from colony to each interpolated position, (5) average bearing and (6) horizontal travel speed (the distance between consecutive locations, divided by duration [60 $\mathrm{min}]$ ).

Colony differences in foraging direction. To compare differences between colonies in the direction of movement during foraging trips, we first calculated the grand mean bearing for each individual (Zar 1996, Hamer et al. 2001). Individuals were then pooled according to colony to compute a mean colony bearing (Zar 1996). We examined each colony to establish whether bearings were uniformly distributed, or whether a preferred direction of travel was evident. This was done by calculating the statistic $r$, a measure of angular dispersion ranging from 0 (no mean angle) to 1 (data concentrated in the same direction) (Zar 1996). We used the Rayleigh test or, if the data were bimodal, the Rao's spacing test. Finally, to test whether mean colony bearings differed, we used the WatsonWilliams F-test.

Meta home range. Austral autumn (April and May) was the only period during which all colonies were represented by tracking data. Therefore, in order to compare meta home ranges among colonies (see Robson et al. 2004), the first foraging trip for each seal during this period was selected for analysis. In addition, Cape du Couedic and Liguanea Island females were also tracked into austral winter months (June and July). Consequently, we selected the first June foraging trip for each of these individuals. For each individual's foraging trip, we randomly sampled 100 interval locations (recorded every $60 \mathrm{~min}$ ) and pooled them according to colony. Meta home ranges were then estimated using $95 \%$ fixed kernel home ranges calculated through the Animal Movement extension (Hooge \& Eichenlaud 1997) within ArcView GIS 3.2a. Meta home ranges were plotted using VerticalMapper (Version 2.5) (MapInfo Corporation) and MapInfo (Version 8.0).
Oceanographic parameters. Sea surface temperature (SST) and surface chl a concentration were calculated for each seal at 15 min intervals along each interpolated satellite track. SST data were obtained from the AVHRR sensor - part of the multi-channel sea surface temperature dataset, compiled by the U.S. Naval Oceanographic Office and distributed by the Global Ocean Data Assimilation Experiment. The surface chlorophyll a data were derived from the moderate resolution imaging spectroradiometer (MODIS) weekly average database, which has a $4 \mathrm{~km}^{2}$ spatial resolution. If daily chlorophyll data were not available, the monthly average was used. The STF was mapped using mean monthly SST temperatures. In April, the STF was identified as the location of a $14^{\circ} \mathrm{C}$ isotherm at the sea surface (James et al. 2002, Tomczak et al. 2004). In June, the STF was defined as the location of the $12^{\circ} \mathrm{C}$ sea surface isotherm. The STF usually lies between 39 and $42^{\circ} \mathrm{S}$ (James et al. 2002).

Site fidelity. Directional persistence between consecutive foraging trips was used as a measure of site fidelity. Site fidelity was analysed by calculating a mean destination bearing from interpolated positions for each foraging trip for each individual. Bonadonna et al. (2001) defined a fidelity index to account for the influence of preferred colony direction on an individual's foraging trip. This study assumed that a preferred direction is a product of fidelity to specific foraging grounds. The $V$-test was used to determine whether the bearing of an individual's consecutive foraging trips differed significantly (Zar 1996).

All tests were conducted using SPSS Ver. 14.0 and the circular statistics package Oriana (V d.02c, Kovach Computing Service). All values are given as means $( \pm \mathrm{SD})$ and are considered significant at the $\mathrm{p}<0.05$ level. Transformations to meet assumptions of normality and homogeneity of variances were performed as necessary. If normality could not be achieved, than equivalent non-parametric tests were used.

\section{RESULTS}

A total of 22 lactating females of Arctocephalus forsteri were satellite tracked from 4 breeding colonies. In April 2005, satellite transmitters were deployed on 7 seals: 5 at Cape Gantheaume and 2 at Cape du Couedic, Kangaroo Island. In April 2006, a total of 15 satellite transmitters were deployed: 5 each at Liguanea Island, North Neptune Island and Cape du Couedic. One satellite transmitter deployed at North Neptune Island stopped transmitting $4 \mathrm{~d}$ into deployment and was excluded from analysis. Individuals were tracked for an average of 5 foraging trips (range: 2 to 19 foraging trips) (Table 1). In total 1707 unfiltered 
locations (Classes A, 0, 1, 2, 3) were recorded from the first foraging trip. Filtering removed 278 locations. After filtering, the average number of locations per day at sea was $5.2 \pm 3.9$ (Cape Gantheaume $4.4 \pm 1.1$, Cape du Couedic $2.1 \pm 0.8$, North Neptune Island $3.0 \pm 2.0$ and Liguanea Island $2.9 \pm 1.0$ ). The maximum straightline distance from a colony during a foraging trip was $887 \mathrm{~km}$, while the longest duration of a foraging trip was $32.4 \mathrm{~d}$, both recorded by lactating females from Liguanea Island. There were no significant intercolony differences in the girth (Kruskal-Wallis $H$-test: $\mathrm{p}=0.42$ ) or length (1-way ANOVA: $F_{3,20}=1.43, \mathrm{p}=$ 0.26 ) of females selected for deployment.

\section{Colony differences in foraging direction and meta home range}

Seals tracked from Cape du Couedic during 2005 and 2006 were pooled due to limited sample size in 2005. A preferred direction of travel was evident for seals foraging from Cape Gantheaume ( $\mathrm{r}=0.841$, Rayleigh test: $p=0.020)$, Cape du Couedic $(r=0.977$,
Rayleigh test: $\mathrm{p}<0.001$ ) and Liguanea Island $(\mathrm{r}=0.945$, Rayleigh test: $p=0.004$ ) (Fig. 2). With the exception of one seal, which foraged on the continental shelf, the other 3 seals from North Neptune Island also exhibited a preferred direction of travel (average bearing $=204 \pm$ $13^{\circ} ; \mathrm{r}=0.976$, Rayleigh test: $\mathrm{p}=0.042$ ). The mean direction of travel differed significantly among breeding sites, with breeding site predicting the bearing of travel (Table 2, Fig. 2). Seals from Cape Gantheaume typically foraged southeast of the colony $\left(141 \pm 34^{\circ}\right)$, while seals from Cape du Couedic foraged south of the colony $\left(188 \pm 12^{\circ}\right)$. Seals from North Neptune Island and Liguanea Island typically foraged south-southwest of their colonies $\left(204 \pm 12^{\circ}\right.$ and $235 \pm 19$, respectively) (Table 2, Fig. 2). Pair-wise comparisons indicated that the difference in mean direction of travel approached significance between Cape du Couedic and North Neptune Island and between North Neptune and Liguanea Island (Table 2).

Differences in $95 \%$ kernel meta home range reflected maximum distances travelled to preferred foraging grounds. Early autumn meta home range size ranged from $13280 \mathrm{~km}^{2}$ for Cape Gantheaume,

Table 1. Arctocephalus forsteri. Summary data for New Zealand fur seal females on their first foraging trip in autumn, sampled from Cape Gantheaume (CG), Cape du Couedic (DC), North Neptune Island (NN) and Liguanea Island (LIG). Mean values $( \pm$ SD). TL: total length

\begin{tabular}{|c|c|c|c|c|c|c|c|c|c|c|}
\hline $\begin{array}{l}\text { Colony } \\
\text { Deployment } \\
\text { date }\end{array}$ & ID & $\begin{array}{c}\mathrm{TL} \\
(\mathrm{cm})\end{array}$ & $\begin{array}{l}\text { Girth } \\
\text { (cm) }\end{array}$ & $\begin{array}{c}\text { Foraging } \\
\text { location }\end{array}$ & $\begin{array}{l}\text { Trip } \\
\text { duration } \\
\text { (d) }\end{array}$ & $\begin{array}{c}\text { Max. } \\
\text { distance } \\
(\mathrm{km})\end{array}$ & $\begin{array}{l}\text { Cumulative } \\
\text { total distance } \\
(\mathrm{km})\end{array}$ & $\begin{array}{c}\text { Total } \\
\text { deployment } \\
\text { period (d) }\end{array}$ & $\begin{array}{c}\text { Total } \\
\text { trip no. }\end{array}$ & $\begin{array}{c}\text { Mean } \\
\text { bearing } \\
\left({ }^{\circ}\right)\end{array}$ \\
\hline \multicolumn{11}{|l|}{ CG } \\
\hline 4 Apr 2005 & 52469 & 138 & 68 & Shelf & 4.5 & 51 & 168 & 28.9 & 4 & $206 \pm 26$ \\
\hline 30 Mar 2005 & 52470 & 130 & 71 & Shelf & 3.3 & 126 & 374 & 29.6 & 5 & $125 \pm 2$ \\
\hline 10 Apr 2005 & 52471 & 137 & 76 & Shelf & 12 & 190 & 526 & 20.7 & 2 & $121 \pm 2$ \\
\hline 6 Apr 2005 & 52473 & 137 & 75 & Shelf & 7.4 & 107 & 296 & 20.4 & 2 & $117 \pm 7$ \\
\hline \multirow{3}{*}{5 Apr 2005} & 52472 & 134 & 76 & Oceanic & 17.2 & 448 & 1144 & 55.2 & 3 & $150 \pm 8$ \\
\hline & Mean & $135 \pm 3$ & $73 \pm 4$ & & $8.9 \pm 5.7$ & $184 \pm 155$ & $502 \pm 382$ & & & \\
\hline & Mean shelf & $136 \pm 4$ & $73 \pm 4$ & & $6.8 \pm 4$ & $119 \pm 57$ & $341 \pm 150$ & & & \\
\hline \multicolumn{11}{|c|}{$100-1+9-1$} \\
\hline 16 Apr 2006 & 52469 & 131 & 65 & Oceanic & 14.8 & 366 & 877 & 72.1 & 4 & $197 \pm 10$ \\
\hline 21 Apr 2006 & 52470 & 122 & 68 & Oceanic & 24.8 & 467 & 1187 & 57.1 & 4 & $199 \pm 10$ \\
\hline 19 Apr 2006 & 52474 & 126 & 65 & Oceanic & 13.5 & 379 & 869 & 65.2 & 5 & $180 \pm 7$ \\
\hline 13 Apr 2005 & 52475 & 137 & 74 & Oceanic & 7.6 & 350 & 830 & 58.8 & 8 & $192 \pm 6$ \\
\hline 14 Apr 2005 & 52476 & 123 & 73 & Oceanic & 15.3 & 450 & 1004 & 41.5 & 3 & $186 \pm 1$ \\
\hline 18 Apr 2006 & 52477 & - & - & Oceanic & 10.8 & 383 & 1394 & 41.6 & 9 & $190 \pm 20$ \\
\hline \multirow[t]{2}{*}{18 Apr 2006} & 55936 & 136 & 63 & Oceanic & 16.5 & 636 & 1456 & 58.7 & 5 & $161 \pm 9$ \\
\hline & Mean & $129 \pm 6$ & $68 \pm 5$ & & $14.8 \pm 5.4$ & $433 \pm 99$ & $1088 \pm 260$ & & & \\
\hline \multicolumn{11}{|c|}{$100-60-1000-200$} \\
\hline 12 Apr 2006 & 52473 & 128 & 70 & Oceanic & 20.2 & 639 & 1542 & 51.4 & 2 & $216 \pm 5$ \\
\hline 12 Apr 2006 & 52475 & 137 & 72 & Oceanic & 13.9 & 455 & 1208 & 38.6 & 2 & $182 \pm 6$ \\
\hline 12 Apr 2006 & 55953 & 136 & 69 & Oceanic & 15.7 & 599 & 1229 & 59.4 & 3 & $208 \pm 2$ \\
\hline \multirow[t]{3}{*}{13 Apr 2006} & 52476 & 140 & 68 & Shelf & 1.5 & 36 & 46 & 27.9 & 19 & $26 \pm 15$ \\
\hline & Mean & $135 \pm 5$ & $70 \pm 2$ & & $12.8 \pm 8.0$ & $432 \pm 275$ & $1007 \pm 658$ & & & \\
\hline & Mean oceanic & $134 \pm 5$ & $70 \pm 2$ & & $16.6 \pm 3$ & $564 \pm 97$ & $1327 \pm 187$ & & & \\
\hline \multicolumn{11}{|c|}{ Nean oceanic $134 \pm 5$ fo \pm 2} \\
\hline 6 Apr 2006 & 52468 & 126 & 74 & Oceanic & 32.4 & 811 & 2047 & 79.3 & 3 & $239 \pm 7$ \\
\hline 4 Apr 2006 & 52472 & 136 & 73 & Oceanic & 17.2 & 661 & 1492 & 70.7 & 4 & $232 \pm 14$ \\
\hline 4 Apr 2006 & 55956 & 129 & 76 & Oceanic & 23.7 & 798 & 2042 & 70.5 & 3 & $211 \pm 17$ \\
\hline 5 Apr 2006 & 55960 & 135 & 79 & Oceanic & 26.4 & 802 & 2114 & 78.9 & 7 & $269 \pm 30$ \\
\hline \multirow[t]{2}{*}{6 Apr 2006} & 55961 & 131 & 76 & Oceanic & 24.6 & 887 & 1990 & 108.5 & 4 & $222 \pm 17$ \\
\hline & Mean & $131 \pm 4$ & $76 \pm 2$ & & $24.9 \pm 5.5$ & $792 \pm 82$ & $1937 \pm 253$ & & & \\
\hline
\end{tabular}



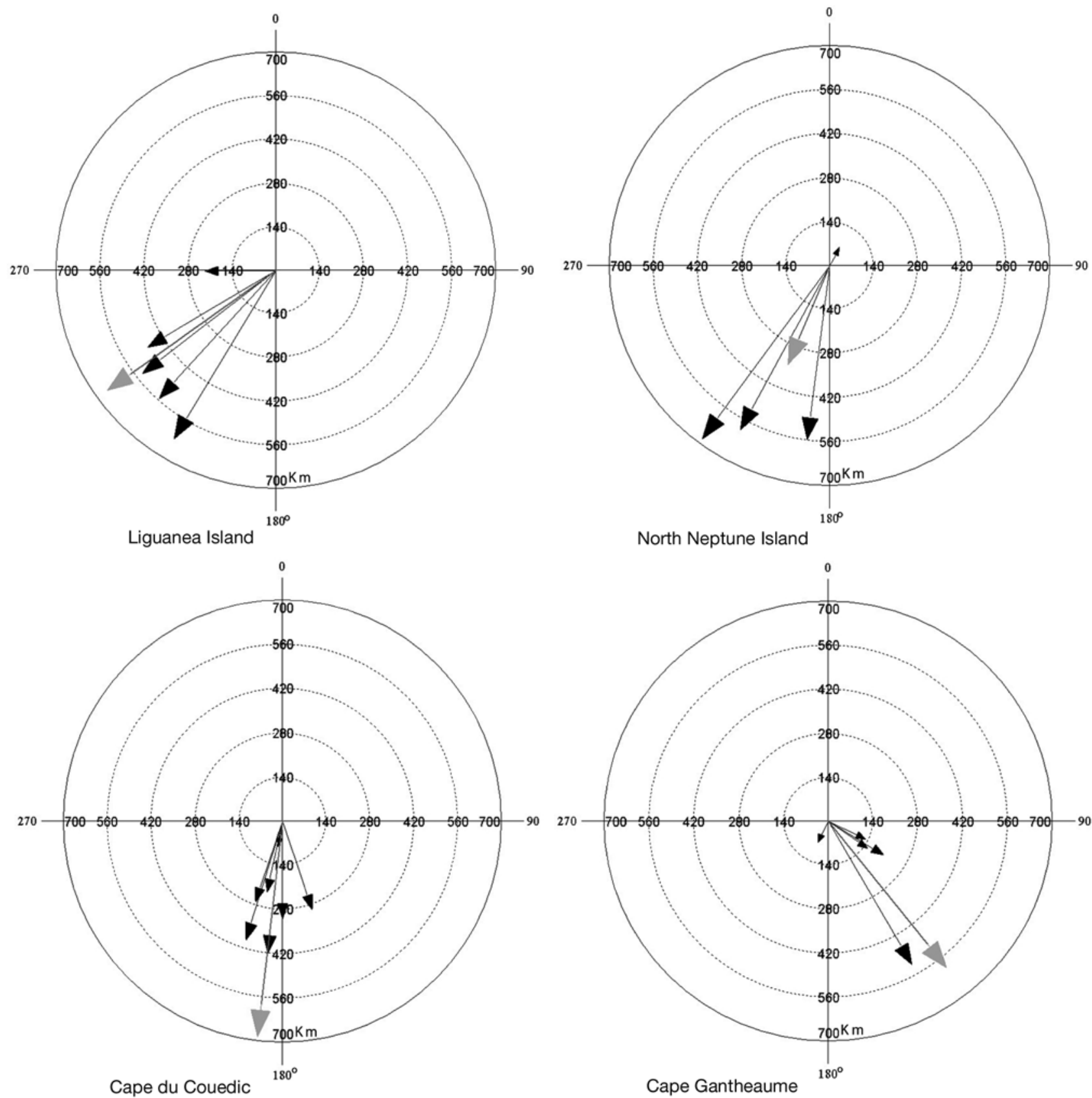

Fig. 2. Arctocephalus forsteri. Mean bearing and mean maximum distance calculated for each individual female New Zealand fur seal sampled from Cape Gantheaume $(n=5)$, Cape du Couedic $(n=7)$, North Neptune Island $(n=4)$ and Liguanea Island $(n=5)$. Presented in order of colony location from west to east. Grey vector denotes mean direction of colony and r-statistic

$54610 \mathrm{~km}^{2}$ for Cape du Couedic, $74180 \mathrm{~km}^{2}$ for North Neptune Island to $172400 \mathrm{~km}^{2}$ for Liguanea Island (Fig. 3). Seals foraging from North Neptune Island overlapped with the meta home range of animals foraging from Liguanea Island and Cape du Couedic. This overlap accounted for $36 \%$ of the meta home range of North Neptune Island $(23 \%$ overlap with Liguanea Island and 13\% overlap with Cape du Couedic).
The winter meta home range for Liguanea Island and Cape du Couedic reflected seasonal differences in distances travelled during foraging trips. The meta home range of seals from Liguanea Island was greater in autumn $\left(172400 \mathrm{~km}^{2}\right)$ compared to winter $\left(33160 \mathrm{~km}^{2}\right)$. Seasonal decline in meta home range size was less pronounced at Cape du Couedic, with autumn and winter meta home area varying from 54610 to $31390 \mathrm{~km}^{2}$, respectively (Fig. 4). 
Table 2. Arctocephalus forsteri. Average colony bearings and associated statistical differences between colonies (Watson-Williams $F$-test), and average linearity indices calculated for 21 lactating New Zealand fur seals from Cape Gantheaume (CG), Cape du Couedic (DC), North Neptune Island (NN) and Liguanea Island (LIG). LI: linearity index. Mean values $( \pm \mathrm{SD})$

\begin{tabular}{|c|c|c|c|c|c|c|c|}
\hline \multirow[t]{2}{*}{ Colony } & \multirow[t]{2}{*}{$\mathrm{n}$} & \multirow{2}{*}{$\begin{array}{c}\text { Mean } \\
\text { bearing }\left({ }^{\circ}\right)\end{array}$} & \multirow[t]{2}{*}{$\mathrm{DC}$} & \multirow[t]{2}{*}{$\mathrm{NN}$} & \multirow[t]{2}{*}{ LIG } & \multirow{2}{*}{$\overline{\text { Outbound }} \mathrm{L}$} & $I$ \\
\hline & & & & & & & Inbound \\
\hline $\mathrm{CG}$ & 5 & $141.6 \pm 34$ & 0.012 & 0.030 & 0.001 & $0.84 \pm 0.11$ & $0.78 \pm 0.16$ \\
\hline DC & 7 & $188 \pm 12$ & & 0.095 & $<0.001$ & $0.85 \pm 0.04$ & $0.83 \pm 0.03$ \\
\hline NN & 3 & $204 \pm 12$ & & & 0.081 & $0.89 \pm 0.03$ & $0.84 \pm 0.04$ \\
\hline LIG & 5 & $235 \pm 19$ & & & & $0.86 \pm 0.07$ & $0.82 \pm 0.09$ \\
\hline
\end{tabular}

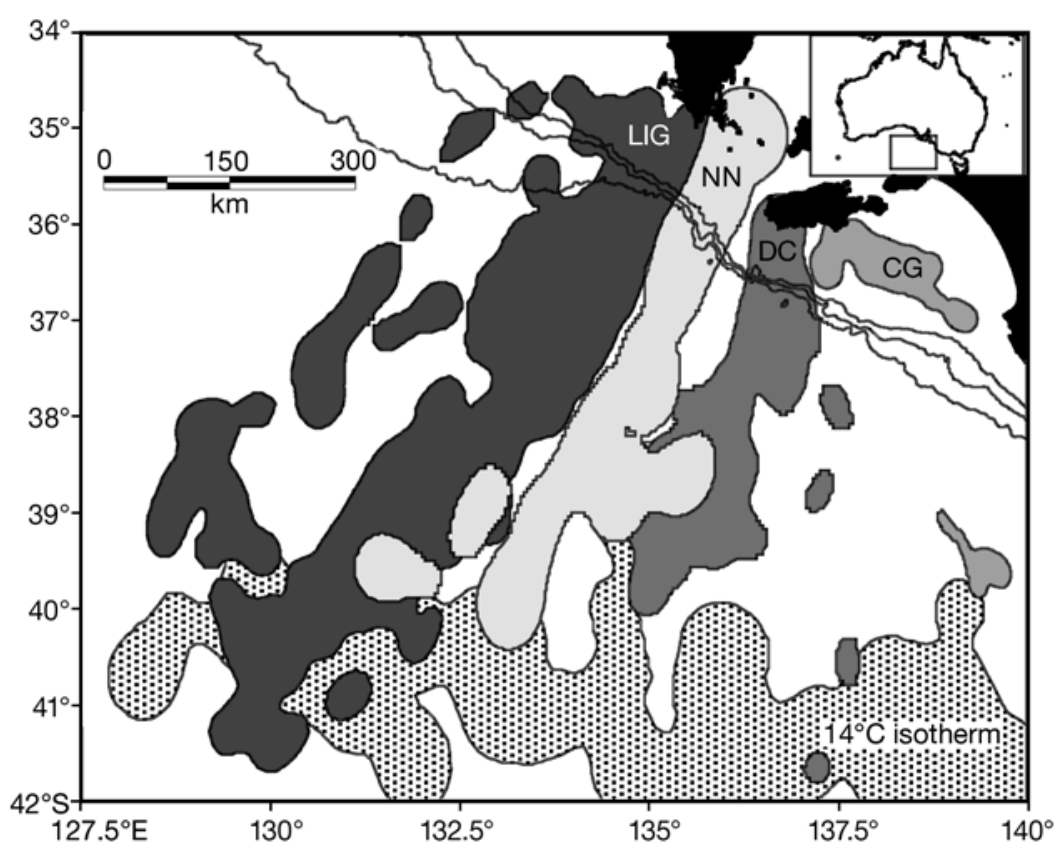

Fig. 3. Arctocephalus forsteri. Autumn meta home range of female New Zealand fur seals from 4 breeding colonies in South Australia: Cape Gantheaume (CG), Cape du Couedic (DC), North Neptune Island (NN) and Liguanea Island (LIG), and aggregated locations of the $14^{\circ} \mathrm{C}$ isotherm for April

\section{Colony differences in oceanography}

In April, females tracked from Cape Gantheaume foraged predominantly on the continental shelf, SE of Cape Gantheaume, in the region associated with the Bonney upwelling. In contrast, females from Cape du Couedic, North Neptune Island and Liguanea Island foraged predominantly off the continental shelf, in the region associated with the STF (39 to $42^{\circ} \mathrm{S}$ ). As such, average SST recorded during foraging trips and experienced by females foraging at the $\operatorname{STF}\left(15.5 \pm 0.31^{\circ} \mathrm{C}\right)$ were lower than those encountered by females foraging on the continental shelf SE of Cape Gantheaume $\left(17.64 \pm 0.92^{\circ} \mathrm{C}\right)$. Seals foraging off the continental shelf spent, on average, $7.6 \%( \pm 5.1)$ of their time in regions of $<14^{\circ} \mathrm{C} \mathrm{SST}, 27.0 \%( \pm 2.7)$ of their time in regions of $14^{\circ} \mathrm{C} \mathrm{SST}$ and $30.2 \%( \pm 2.7)$ of their time in regions of $15^{\circ} \mathrm{C}$ SST (Fig. 5). This finding suggests that seals spent more time at the northern boundary of the STF. During April and May, the average location of the STF (relative to the average colony bearing) was $700 \mathrm{~km}$ from Liguanea Island $\left(39.75^{\circ} \mathrm{S}, 130.45^{\circ} \mathrm{E}\right), 520 \mathrm{~km}$ from North Neptune Island $\left(39.51^{\circ} \mathrm{S}, 133.56^{\circ} \mathrm{E}\right)$, $400 \mathrm{~km}$ from Cape du Couedic $\left(39.54^{\circ} \mathrm{S}\right.$, $135.89^{\circ} \mathrm{E}$ ) and $460 \mathrm{~km}$ away from Cape Gantheaume $\quad\left(39.57^{\circ} \mathrm{S}, \quad 140.34^{\circ} \mathrm{E}\right)$. Average surface chlorophyll a values recorded during foraging trips indicated the Bonney upwelling region was significantly higher in surface chlorophyll a values when compared to the STF $(0.45 \pm 0.10$ compared to $0.19 \pm$ $0.001 \mathrm{mg} \mathrm{m} \mathrm{m}^{-3}$, respectively) (1-way ANOVA: $\left.F_{1,20}=26.4, \mathrm{p}<0.001\right)$.

\section{Distance and duration of foraging trips}

Colonies differed significantly in the maximum straight-line distance travelled (1-way ANOVA: $F_{3,20}=12.9, \mathrm{p}<$ 0.001 ) and the cumulative total distance travelled (1-way ANOVA: $F_{3,20}=11.8$, $\mathrm{p}<0.001)$. Seals tracked from Cape Gantheaume foraged closer to the colony $(184 \pm 155$ or $119 \pm 57 \mathrm{~km}$, excluding the one female foraging at the STF), when compared to seals from Cape du Couedic $(433 \pm 99 \mathrm{~km})$, North Neptune Island (564 $\pm 97 \mathrm{~km}$ excluding the one female that foraged on the continental shelf) and Liguanea Island (792 $\pm 82 \mathrm{~km})$. In addition, females tracked from Liguanea Island travelled significantly greater cumulative total distances when compared with those for Cape Gantheaume, Cape du Couedic and females from North Neptune Island foraging at the STF (1-way ANOVA: $F_{3,19}=21.4$, $\mathrm{p}<0.001$; Tukey HSD-test: $\mathrm{p}<0.05$ in all cases). These differences were correlated with the distance of colonies from the STF, or, in the case of on-shelf foragers at Cape Gantheaume, the Bonney upwelling.

The durations of foraging trips were positively correlated with maximum distance travelled (regression: $F_{1,20}=63, \mathrm{p}<0.001, \mathrm{r}=0.76$ ). Females from Liguanea Island recorded significantly longer foraging trip durations than those from all other colonies $(24.9 \pm 5.0 \mathrm{~d})$ $\left(F_{3,20}=12.9, \mathrm{p}<0.001\right.$; Tukey HSD: $\mathrm{p}<0.05$ all compar- 


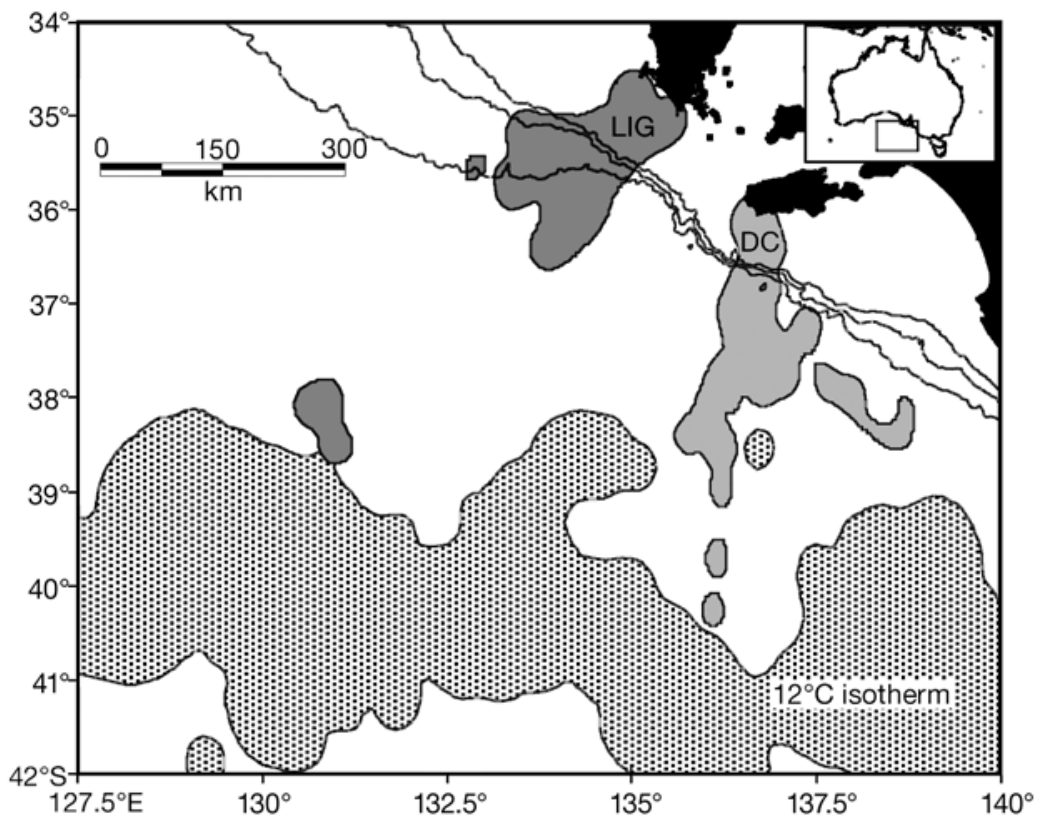

Fig. 4. Arctocephalus forsteri. Winter meta home range of female New Zealand fur seals from Cape du Couedic (DC) and Liguanea Island (LIG), and the aggregated locations of the $12^{\circ} \mathrm{C}$ isotherm in June
Along with Cape Gantheaume females, some seals from Cape du Couedic, Liguanea Island and North Neptune Island were also recorded to forage on the continental shelf. The female from North Neptune Island travelled north of the colony, to utilise the lower Spencer Gulf region (Fig. 3, Table 1). During winter, a single female from Cape du Couedic and one from Liguanea Island deviated from oceanic foraging trips in early autumn to forage on the continental shelf. The Cape du Couedic seal tracked on the continental shelf foraged south-southwest of the colony (maximum distance: $40 \mathrm{~km}$, duration $1.5 \mathrm{~d}$ ). Similarly, the Liguanea Island female utilised the shelf region SW of Liguanea Island during winter (maximum distance: $60 \mathrm{~km}$, duration: $5.9 \mathrm{~d}$ ). At Cape du Couedic, the maximum distance and duration of foraging trips to oceanic waters did not differ significantly between autumn and winter $(p>0.05$ in all cases). Conversely, females from Liguanea Island foraged significantly closer to the colony during winter compared to autumn $(267 \pm 206 \mathrm{~km}$ and $792 \pm 82 \mathrm{~km}$, respectively; repeated measures ANOVA: $F_{2,4}=41.5$, $\mathrm{p}=0.003$ ), although foraging trip durations were not significantly shorter (repeated measures ANOVA: $F_{2,4}=4.6, \mathrm{p}=0.097$ ) (Table 3).

\section{Individual movement and site fidelity}

Typically, females travelled directly to and from foraging grounds. On average, the LI for the outbound portion of foraging trips was $0.85 \pm 0.07$ (range: 0.69 to 0.99 ) and for the return portion of the foraging trip was $0.82 \pm 0.09$ (range: 0.49 to 0.94 ). The LI for each colony is presented in Table 2. The outbound and inbound portions of foraging trips were also characterised by relatively high swimming speeds $(3.2 \pm 0.9$ and $3.4 \pm$ $0.8 \mathrm{~km} \mathrm{~h}^{-1}$, respectively). Once at a foraging site, the direction of movement was variable (average LI $=0.31$ \pm 0.07 , range: 0.16 to 0.44 ), with lower horizontal travel speeds $\left(1.31 \pm 0.6 \mathrm{~km} \mathrm{~h}^{-1}\right)$, presumably associated with searching for prey (Weimerskirch 2007). The average difference between the directions of consecutive foraging trips for all females was $10.8 \pm 7.9^{\circ}$ (range: 1.3 to $30.4^{\circ}$ ) (Table 1). There was no significant difference in the average bearing of individual's consecutive foraging trips, despite trips being 12 to $108 \mathrm{~d}$ apart ( $V$-test: $\mathrm{p} \leq 0.001$ in all cases). isons). Foraging trip duration did not differ significantly between Cape Gantheaume (8.9 $\pm 5.7 \mathrm{~d})$, Cape du Couedic (14.8 $\pm 5.4 \mathrm{~d}$ ) and North Neptune Island (16.6 \pm $3.0 \mathrm{~d})$ ( $\mathrm{p}>0.05$ ). Similarly, the average travel speed of females did not differ significantly between colonies (1-way ANOVA: $F_{3,20}=1.26, p=0.32$ ). 
Table 3. Arctocephalus forsteri. Summary data for New Zealand fur seal females on their first foraging trip in winter, sampled from Cape du Couedic (DC) and Liguanea Island (LIG). Mean values $( \pm \mathrm{SD})$

\begin{tabular}{|c|c|c|c|c|c|}
\hline Colony & ID & $\begin{array}{l}\text { Foraging } \\
\text { location }\end{array}$ & $\begin{array}{l}\text { Trip duration } \\
\text { (d) }\end{array}$ & $\begin{array}{l}\text { Max. distance } \\
(\mathrm{km})\end{array}$ & $\begin{array}{l}\text { Cumulative } \\
\text { total distance }(\mathrm{km})\end{array}$ \\
\hline \multirow[t]{9}{*}{ DC } & 52469 & Oceanic & 21.42 & 491 & 1026 \\
\hline & 52470 & Oceanic & 16.29 & 219 & 726 \\
\hline & 52474 & Oceanic & 13.58 & 217 & 508 \\
\hline & 52475 & Oceanic & 6.00 & 172 & 453 \\
\hline & 52476 & Oceanic & 16.42 & 459 & 1194 \\
\hline & 55936 & Oceanic & 12.08 & 323 & 748 \\
\hline & 52477 & Shelf & 1.54 & 40 & 93 \\
\hline & Mean & & $12.5 \pm 6.7$ & $274 \pm 160$ & $678 \pm 369$ \\
\hline & an ocear & & $14.3 \pm 5.2$ & $313 \pm 135$ & $776 \pm 289$ \\
\hline \multirow[t]{7}{*}{ LIG } & 52468 & Oceanic & 5.96 & 136 & 344 \\
\hline & 52472 & Oceanic & 8.38 & 227 & 567 \\
\hline & 55956 & Oceanic & 21.50 & 320 & 1333 \\
\hline & 55961 & Oceanic & 25.63 & 591 & 1482 \\
\hline & 55960 & Shelf & 5.92 & 60 & 149 \\
\hline & Mean & & $13.5 \pm 9.4$ & $267 \pm 206$ & $775 \pm 598$ \\
\hline & an ocear & & $15.4 \pm 9.7$ & $319 \pm 197$ & $931 \pm 560$ \\
\hline
\end{tabular}

\section{DISCUSSION}

Both colony location and proximity to key oceanographic features influenced the spatial distribution of foraging effort of female New Zealand fur seals Arctocephalus forsteri. Based on maximum foraging distances, individuals from different colonies had the potential to overlap considerably in their foraging locations. However, our data showed that overlap between meta home ranges was limited, and there was a clear separation of foraging areas between colonies. While it cannot be discounted that the observed separation of foraging areas may be an effect of small sample size, data collected from multiple foraging trips provide a compelling case, our results suggesting that lactating New Zealand fur seals commenced foraging trips on a pre-determined bearing. The findings of our study are consistent with studies on Antarctic and northern fur seals, and colonial breeding sea birds (Boyd et al. 2002, Gremillet et al. 2004, Robson et al. 2004). These studies suggest that colony-based separation of foraging habitat is a common strategy utilised in colonial breeding seabirds and seals to reduce competition for resources among meta-populations.

\section{Oceanographic features}

During autumn, lactating New Zealand fur seals from Cape du Couedic, North Neptune Island and Liguanea Island predominantly utilised distant oceanic waters associated with the STF. The correlation between oceanic fronts and the distribution of foraging effort in seabirds and marine mammals is well established (e.g. Georges et al. 2000, Charrassin \& Bost 2001, Spear et al. 2001). Frontal zones are generally accompanied by sharp salinity and temperature gradients that influence the exchange and mixing of marine resources and are characterised as regions of enhanced biological activity, where prey species may be concentrated (Spear et al. 2001). Although the STF is relatively weak compared with other frontal systems, it is a distinctive feature in any meridional crossing south of Australia and has been described as a region of high productivity (James et al. 2002, Tomczak et al. 2004).

In contrast to other colonies, females from Cape Gantheaume predominantly foraged on the continental shelf in autumn, in a region associated with the Bonney upwelling. The differences observed in the distribution of foraging effort between seals from Cape Gantheaume and all other colonies reflect the proximity of this colony to a seasonally predictable and productive coastal upwelling feature. Coastal upwellings in close proximity to Cape du Couedic, North Neptune Island and Liguanea Island colonies are also known to enhance productivity during summer and autumn months through the upwelling of the Flinders current (Kampf et al. 2004). These upwellings are a regional extension of the Bonney upwelling, but are less prominent and predictable when compared to the area where the seals from Cape Gantheaume foraged (Butler et al. 2002, Kampf et al. 2004). Consequently, the extended distances travelled by seals from Cape du Couedic, North Neptune Island and Liguanea Island colonies suggests the STF is likely to be less variable and more predictable than neritic or shelf-slope habitats near these colonies.

\section{Trip duration and individual movement}

The duration of foraging trips and distances travelled by New Zealand fur seals are among the longest documented for lactating fur seals. However, foraging trips longer than $20 \mathrm{~d}$, which exceed distances of $500 \mathrm{~km}$, are not unusual for temperate fur seals that have protracted lactation periods. Similar distances and durations have also been recorded in lactating Guadalupe Arctocephalus townsendi and Juan Fernandez A. philippii fur seals (Francis et al. 1998). In lactating subAntarctic fur seals A. tropicalis, the duration of forag- 
ing trips have been recorded to be as long as $54 \mathrm{~d}$, with maximum distances from the breeding colony greater than $1600 \mathrm{~km}$ (Beauplet et al. 2004). The extended foraging trips of these temperate and sub-Antarctic species are thought to reflect a degree of flexibility in their provisioning strategy, which is necessary for long lactation periods that encompass seasonal changes and variability in ocean productivity (Beauplet et al. 2004).

Extended foraging trips are performed to enable exploitation of distant and productive regions. Whilst these trips incur greater travel costs, they are likely to be profitable as they target regions such as frontal zones where there is a high chance of encountering suitable prey over an extended period (Weimerskirch et al. 2005). The predictability of fur seal foraging habitats is evident in the fact that fur seals tend to target the same oceanographic features between years (Bonadonna et al. 2001, Boyd et al. 2002, Robson et al. 2004). Predictability in the location of resources allows individuals to travel directly to known regions and thereby maximise foraging efficiency (Bonadonna et al. 2001). In our study, females travelled directly to foraging areas (i.e. 'commuted'). This behaviour has been reported for a number of other fur seal species targeting productive ocean features. For example, lactating sub-Antarctic fur seals from Amsterdam Island travelled directly to the STF region to forage (Georges et al. 2000) and Antarctic and northern fur seals commuted rapidly to shelf-break regions around the Kerguelen and Pribilof Islands, respectively (Bonadonna et al. 2001, Robson et al. 2004).

The current study found that upon reaching a foraging site, New Zealand fur seals reduced their horizontal travel speed and increased their turning rate. This behaviour is consistent with area-restricted search, where individuals increase their search effort in areas where prey are more likely to be encountered (Weimerskirch 2007). This pattern of habitat utilisation reflects a hierarchical patch system, which describes high-density, small-scale patches that are nested within low-density, large-scale patches (Fauchald et al. 2000). In the case of fur seals, individuals tend to target seasonally predictable large-scale oceanographic features (frontal zones, coastal upwellings, shelf-break regions) within which they search for patchily distributed prey (Bonadonna et al. 2001).

\section{Colony separation and site fidelity}

The distribution of predator populations is often found to be proportional to the distribution of resources (Fretwell \& Lucas 1970). Thus, it is reasonable to assume the distribution and spatial density of New
Zealand fur seal populations in southern Australia reflects the accessibility and predictably of prey resources and proximity to suitable breeding habitat. With this in mind, density-dependent foraging habitat selection and predictions of the ideal free distribution (IFD) (Fretwell \& Lucas 1970, Sutherland 1983) may provide a framework to explain the evolution and maintenance of colony-specific foraging areas in colonial breeding seals and seabirds. According to the IFD, individuals distribute foraging effort between habitat patches according to the density of conspecifics and associated density-dependent regulatory effects on resources (Maguire et al. 2006). When the IFD is reached (equilibrium), animals can no longer increase their resource intake rate by moving between patches such as the average gain is predicted to be equal for all individuals regardless of the patch they occupy (Moody \& Houston 1995). The predictable nature of the STF and its occurrence as a continuous feature south of Australia may provide equal access to relatively predictable resources for New Zealand fur seals from all colonies. If we assume each colony's foraging area (or patch) is more or less equal in quality, then under the IFD there is no benefit for individuals to forage in different colony-specific foraging grounds (or patches), where increased interference from competition with conspecifics may reduce foraging success. Thus, the probability of animals moving between colony-specific foraging grounds should depend on fitness costs (Nichols \& Kendall 1995).

The question of how fur seals are able to persistently initiate a foraging trip on a similar bearing and exhibit such strong fidelity to foraging grounds is less intuitive. Little is known about how an individual's decisions influence the collective spatial distribution of colony foraging effort, or if colony-preferred bearings are related to cultural foraging patterns governed by philopatry as has been speculated for Cape gannets Morus capensis (Gremillet et al. 2004). In the case of New Zealand fur seals, proximal cues such as bathymetric features and colony orientation do not adequately explain colony-specific bearings, as found by Boyd et al. (2002) for Antarctic fur seals at South Georgia. Seasonal differences in foraging location indicate that, even when trip distance and duration differed, New Zealand fur seals foraged along the same colonyspecific bearing. These results are similar to those of Bonadonna et al. (2001) and Robson et al. (2004), who noted interannual persistence of colony-specific bearings, and suggest that seals learn the direction of travel to a predictable foraging region (i.e. STF and Bonney upwelling region), and initiate a foraging trip on that bearing. This type of memory-based knowledge is effective from an optimal foraging perspective, be- 
cause it allows direct travel to known foraging regions. However, actual foraging routes are likely to be influenced by a number of factors, including previous foraging trip experience, local environmental cues and the distribution of preferred prey patches (Bonadonna et al. 2001, Boyd et al. 2002, Robson et al. 2004). Finally, in the case of central place foragers, philopatry to breeding site is likely to be important in disseminating and reinforcing colony-specific foraging routes (Robson et al. 2004). For long-lived species, fidelity to foraging site may be advantageous because familiarity with a particular area may enhance foraging success and maximise energy gain over the lifetime of an animal (Gentry 1998, Robson et al. 2004, Bradshaw et al. 2004).

\section{Considerations for management}

Based on the colony-specific foraging areas of lactating New Zealand fur seals described in the present study, there are likely to be spatial variations in the effect of operational and trophic interactions associated with commercial fishing activity. Management of these interactions will be specific for each fishery and will primarily be based on the degree of spatial overlap between seals and fishing activity. The majority of fishing operations in South Australia take advantage of the prevalence of commercial quantities of important fish species over the continental shelf and shelf-break regions (Caton \& McLoughlin 2005, Linnane et al. 2006, Rogers \& Ward 2006). As such, the likelihood of interaction will be greater between December and February, when pups are young and lactating seals are likely to be limited to foraging over the continental shelf, close to their colonies (Harcourt et al. 2002, Page et al. 2006). Furthermore, there is an increased likelihood of interaction during late winter, when seals may forage closer to the continental shelf, as observed in the present study.

In general, on-shelf foragers that spend time within marine fishery areas with low commercial fishing effort (such as those from Liguanea Island and Cape du Couedic) are less likely to interact with fisheries. On the other hand, on-shelf foragers that spend proportionally more time foraging within areas of high fishing effort (such as those from Cape Gantheaume and North Neptune Island) are more likely to interact with commercial fisheries (Caton \& McLoughlin 2005, Linnane et al. 2006, Rogers \& Ward 2006). Therefore, consideration for future fisheries management may be necessary for regions were fur seal foraging effort overlaps with significant commercial fishing effort, whereas a similar focus may be unnecessary at sites where the likelihood of interactions is relatively low.
Acknowledgements. This study was supported through the Fisheries Research and Development Corporation (FRDC) Grants Scheme (PN 2005/031), Nature Foundation SA, Wildlife Conservation Fund, Holsworth Wildlife Fund, MA Ingram Trust and the Sea World Research and Rescue Foundation. A.M.M.B. received an Australian postgraduate award to conduct this project. We thank T. Ward for securing FRDC funding and ongoing support of the project. M. Coyne provided chlorophyll a data. We thank the many volunteers who assisted with fieldwork, in particular, C. Iriarte, D. Lierich and C. 'dutchie' Pleuis. We gratefully acknowledge the support of 'Pelagic' charter boat operators S. and B. Cole and also thank the continued support of DEH Kangaroo Island, in particular, B. Haddrill, D. Heard, D. Snowball and A. Maguire. Finally, we extend our gratitude to D. Paton for his ongoing support. K. Collins, D. Hamer and 2 anonymous reviewers improved this manuscript with valuable comments and suggestions. This research was conducted under Adelaide University animal ethics Permit S80-2004 and Department for Environment and Heritage Permit A24684-3.

\section{LITERATURE CITED}

Ainley DG, Ribic CA, Ballard G, Heath S and others (2004) Geographic structure of Adelie penguin populations: overlap in colony-specific foraging areas. Ecol Monogr 74(1):159-178

Beauplet G, Dubroca L, Guinet C, Cherel Y, Dabin W, Gagne C, Hindell M (2004) Foraging ecology of subantarctic fur seals Arctocephalus tropicalis breeding on Amsterdam island: seasonal changes in relation to maternal characteristics and pup growth. Mar Ecol Prog Ser 273:211-225

Bernstein C, Kacelnik A, Krebs JR (1991) Individual decisions and the distribution of predators in a patchy environment. II. The influence of travel costs and structure of the environment. J Anim Ecol 60:205-225

Bonadonna F, Lea MA, Dehorter O, Guinet C (2001) Foraging ground fidelity and route-choice tactics of a marine predator: the Antarctic fur seal Arctocephalus gazella. Mar Ecol Prog Ser 223:287-297

Boyd IL, Staniland IJ, Martin AR (2002) Distribution of foraging by female Antarctic fur seals. Mar Ecol Prog Ser 242: 285-294

Bradford-Grieve JM, Boyd PW, Chang FH, Chiswell S and others (1999) Pelagic ecosystem structure and functioning in the subtropical front region east of New Zealand in austral winter and spring 1993. J Plankton Res 121(3): 405-428

Bradshaw CJ, Hindell MA, Sumner MD, Michael KJ (2004) Loyalty pays: potential life history consequences of fidelity to marine foraging regions by southern elephant seals. Anim Behav 68:1349-1360

Brothers N, Gales R, Hedd A, Roberston G (1998) Foraging movements of the shy albatross Diomedea cauta breeding in Australia: implications for interactions with longline fisheries. Ibis 140:446-457

Butler A, Althaus F, Furlani D, Ridgway K (2002) Assessment of the conservation values of the Bonney upwelling area: $\mathrm{a}$ component of the Commonwealth Marine Conservation Assessment Program 2002-2004. Report to Environment Australia. CSIRO Marine Research, Hobart

Caton A, McLoughlin K (2005) Fishery status reports 2005: status of fish stocks managed by the Australian Government. Bureau of Rural Sciences, Canberra

Charrassin JB, Bost CA (2001) Utilisation of the oceanic habitat by king penguins over the annual cycle. Mar Ecol Prog Ser 221:285-297 
Fauchald P, Erikstad KE, Skarsfjord H (2000) Scale-dependent predator-prey interactions: the hierarchical spatial distribution of seabirds and prey. Ecology 81:773-783

Francis J, Boness D, Ochoa-Acuna H (1998) A protracted foraging and attendance cycle in female Juan Fernandez fur seals. Mar Mamm Sci 14(3):552-574

Fretwell SD, Lucas HL (1970) On territorial behaviour and other factors influencing habitat distribution in birds. Acta Biotheor 19:16-36

Gentry RL (1998) Site fidelity and philopatry. In: Gentry RL (ed) Behaviour and ecology of the northern fur seal. Princeton University Press, Princeton, NJ, p 153-166

Georges JY, Bonadonna F, Guinet C (2000) Foraging habitat and diving activity of lactating subantarctic fur seals in relation to sea-surface temperatures at Amsterdam Island. Mar Ecol Prog Ser 196:291-304

Goldsworthy SD, Bulman C, He X, Larcombe J, Littnan C (2003) Trophic interactions between marine mammals and Australian fisheries: an ecosystem approach. In: Gales N, Hindell M, Kirkwood R (eds) Marine mammals and humans: fisheries, tourism and management. CSIRO Publications, Hobart, p 62-99

Grémillet D, Dell'Omo G, Ryan PG, Peters G, Ropert-Coudert Y, Weeks SJ (2004) Offshore diplomacy, or how seabirds mitigate intra-specific competition: a case study based on GPS tracking of Cape gannets from neighboring colonies. Mar Ecol Prog Ser 268:265-279

Hamer KC, Phillips RA, Hill JK, Wanless S, Wood AG (2001) Contrasting foraging strategies of gannets Morus bassanus at two North Atlantic colonies: foraging trip duration and foraging area fidelity. Mar Ecol Prog Ser 224:283-290

Harcourt RG, Bradshaw CJA, Dickson K, Davis LS (2002) Foraging ecology of a generalist predator, the female New Zealand fur seal. Mar Ecol Prog Ser 227:11-24

Hooge PN, Eichenlaub B (1997) Animal movement extension to ArcView 1.1. Alaska Biological Science Centre, U.S. Geological Survey, Anchorage, AK

Irons DB (1998) Foraging area fidelity of individual seabirds in relation to tidal cycles and flock feeding. Ecology 79(2): 647-655

James C, Tomczak M, Helmond I, Pender L (2002) Summer and winter surveys of the subtropical front of the southeastern Indian Ocean 1997-1998. J Mar Syst 37:129-149

Kampf J, Doubell M, Griffin D, Matthews RL, Ward TM (2004) Evidence of a large seasonal coastal upwelling system along the southern shelf of Australia. Geophys Res Lett 31:1-4

Kostianoy AG, Ginzburg AI, Frankignoulle M, Delille B (2004) Fronts in the Southern Indian Ocean as inferred from satellite sea surface temperature data. J Mar Syst 45: $55-73$

Lea MA, Hindell M, Guinet C, Goldsworthy S (2002) Variability in the diving activity of Antarctic fur seals, Arctocephalus gazella, at Iles Kerguelen. Polar Biol 25:269-279

Lewis RK (1981) Seasonal upwelling along the south-eastern coastline of South Australia. Aust J Mar Freshw Res 32: 843-854

Linnane A, McGarvey R, Feenstra J, Ward TM (2006) Southern zone rock lobster (Jasus edwardsii) fishery 2004/05: final stock assessment report to PIRSA fisheries RD/04/ 0164-3. SARDI Aquatic Sciences, Adelaide

Maguire G, Ramp D, Coulson G (2006) Foraging behaviour

Editorial responsibility: Otto Kinne,

Oldendorf/Luhe, Germany and dispersion of eastern grey kangaroos (Macropus giganeus) in an ideal free framework. J Zool 268:261-269

Matthiopoulos J, Harwood J, Thomas L (2005) Metapopulation consequences of site fidelity for colonially breeding mammals and birds. J Anim Ecol 74:716-727

McConnell BJ, Chambers C, Fedak MA (1992) Foraging ecology of southern elephant seals in relation to the bathymetry and productivity of the Southern Ocean. Antarct Sci 4: 393-398

Moody AL, Houston AI (1995) Interference and the ideal free distribution. Anim Behav 49:1065-1072

Nichols JD, Kendall WL (1995) The use of multi-state capture-recapture models to address questions in evolutionary ecology. J Appl Stat 22:835-846

Orians GH, Pearson NE (1979) On the theory of central place foraging. In: Horn DJ, Stairs GR, Mitchell RD (eds) Analysis of ecological systems. Ohio State University Press, Columbus, OH, p 155-177

Page B, McKenzie J, Sumner MD, Coyne M, Goldsworthy SD (2006) Spatial separation of foraging habitats among New Zealand fur seals. Mar Ecol Prog Ser 323:263-279

Robson BW, Goebel ME, Baker JD, Ream RR, Loughlin TR, Francis RC, Antonelis GA, Costa DP (2004) Separation of foraging habitat among breeding sites of a colonial marine predator, the northern fur seal (Callorhinus ursinus). Can J Zool 82:20-29

Rogers PJ, Ward TM (2006) Fishery assessment report: Australian sardine (pilchard) 2005; report to PIRSA fisheries RD/03/0198-3. SARDI Aquatic Sciences, Adelaide

Shaughnessy PD (2005) Population assessment of New Zealand fur seals and Australian sea lions at some colonies in South Australia, 2004-05. CSIRO Sustainable Ecosystems, Canberra

Spear LB, Balance LT, Ainley DG (2001) Response of seabirds to thermal boundaries in the tropical Pacific: the thermocline versus the equatorial front. Mar Ecol Prog Ser 219: 275-289

Staniland IJ, Boyd IL (2003) Variation in the foraging location of Antarctic fur seals (Arctocephalus gazella) and the effects on diving behaviour. Mar Mamm Sci 19:331-343

Sutherland WJ (1983) Aggregation and the 'ideal free' distribution. J Anim Ecol 52:821-828

Switzer PV (1993) Site fidelity in predictable and unpredictable habitats. Evol Ecol 7:533-555

Thompson D, Moss SEW, Lovell P (2003) Foraging behaviour of South American fur seals Arctocephalus australis: extracting fine scale foraging behaviour from satellite tracks. Mar Ecol Prog Ser 260:285-296

Tomczak M, Pender L, Liefrink S (2004) Variability of the subtropical front in the Indian Ocean south of Australia. Ocean Dyn 54:506-519

Wanless S, Harris MP (1993) Use of mutually exclusive foraging areas by adjacent colonies of blue-eyed shags (Phalacrocorax atriceps) at South Georgia. Colon Waterbirds 16(2):176-182

Weimerskirch H (2007) Are seabirds foraging for unpredictable resources? Deep-Sea Res II 54:211-223

Weimerskirch H, Gault A, Cherel Y (2005) Prey distribution and patchiness: factors in foraging success and efficiency of wandering albatrosses. Ecology 86(10):2611-2622

Zar JH (1996) Biostatistical analysis. Prentice-Hall, Upper Saddle River, NJ

Submitted: January 19, 2007; Accepted: September 21, 2007

Proofs received from author(s): February 15, 2008 